\title{
External Sphincter Injection of Onabotulinum-A Toxin in Treatment of Children with Bladder- Sphincteric Dyssynergia
}

\author{
ABOURJILA A. GAMAL ELDIN, M.D.; AYMAN M. GABR, M.D.; AMR M. ELSOFY, M.D. and \\ MOHAMED FAWZY, M.D.
}

The Department of Urology, National Institute of Urology and Nephrology, Cairo, Egypt

\begin{abstract}
Background: The first application of Onabotulinum-A Toxin in urology was its injection into the urinary sphincter to treat neurogenic detrusor-sphincter dyssynergia in quadriplegic men. Since that first report by Dyskatra et al., in 1988, the results of focal Onabotulinum-A Toxininjections into the sphincter, the bladder wall and lately into the prostate have raised the interest of the urology community in this promising new therapeutic modality. This is an evidence-based review of the current indications, techniques and outcomes of Onabotulinum-A Toxin injections into the urethral sphincter.
\end{abstract}

Aim of Study: We evaluated the effect of detrusor injection of onabotulinum-A toxin into the urethral urinary sphincter in children with bladder-external sphincter dyssynergia to decrease urethral resistance and improve voiding.

Material and Methods: Prospective treatment was performed in 25 children 4 to 15 years old (mean age 7 ) with bladder-neck dyssynergia using onabotulinum-A toxin. Preoperatively all children were evaluated by ultrasound, voiding cystourethrography, excretory urography, magnetic resonance imaging and urodynamic studies, including pressure flow, electromyography and uroflowmetry. Using a rigid pediatric endoscope and a $4 \mathrm{Fr}$ injection needle 50 to $100 \mathrm{IU}$ onabotulinum-A toxin was injected into the external sphincter at the 5 and 7 o'clock positions. Follow-up was 6 to 15 months. Repeat injections every 6 months were given according to the response with a maximum of 3 injections.

Results: Immediately after onabotulinum-A toxin injection all except 1 patient were able to void without catheterization. No acute complications occurred. Postoperatively post-void residual urine decreased by $30 \%$, detrusor leak point pressure decreased significantly by a mean \pm SD of $66 \pm 18$ vs $37 \pm 4 \mathrm{~cm}$ $\mathrm{H} 2 \mathrm{O}$ and uroflowmetry showed a marked increase in maximum urine flow of $7 \pm 2$ vs $17.3 \pm 8 \mathrm{ml}$ per second.

Conclusions: Urethral sphincter onabotulinum-A toxin injection could be considered a reliable treatment modality in children with nonneurogenic neurogenic bladder after the failure of conservative therapy.

Key Words: Onabotulinum-A toxin - Nonneurogenic neurogenic bladder-Bladder-neck dyssynergia - Bladder-external sphincter dyssynergia.

Correspondence to: Dr. Abourjila A. Gamal Eldin, The Department of Urology, National Institute of Urology and Nephrology, Cairo, Egypt

\section{Introduction}

DYSSYNERGIA is the kinesiologic disassociation of two groups of muscles that, in general, work in harmony. Sphincter dyssynergia is an involuntarycontraction, or lack of relaxation, of the striated sphincter. The storage phase of the bladder can be switched to the voiding phase either involuntarily (reflexively) or voluntarily. The former is readily demonstrated in the human infant or in patients with neuropathic bladder when the bladder wall tension due to increased volume of urine exceeds the micturition threshold. At this point, increased afferent firing from tension receptors in the bladder reverses the pattern of efferent outflow, producing firing in the sacral parasympathetic pathways and inhibition of sympathetic and somatic pathways. The expulsion phase consists of an initial relaxation of the external urethral sphincter followed in a few seconds by a contraction of the bladder, an increase in bladder pressure, and the flow of urine. During the storage phase, the lumbosacral efferent pathways in the pudendal nerves provide cholinergic excitatory inputs to the striated muscle of the urethral sphincter [1].

During voiding, three changes are occurred and coordinated by three sets of nerves (parasympathetic, sympathetic, and somatic) that emerge from the sacral and thoracolumbar spinal cord [1]

Sacral parasympathetic (pelvic) nerves provide excitatory inputs (cholinergic and purinergic) to the bladder and have an inhibitory (nitrergic) effect on the smooth urethral sphincter $[2,3]$. Secondary reflexes elicited by flow of urine through the urethra facilitate bladder emptying. These reflexes require the integrative action of neuronal populations at various levels of the neuraxis [4].

Stoffel et al., [5] published a consensus paper on the management of nonneurogenic urinary re- 
tention, defined as a postvoid residual above $300 \mathrm{~mL}$ that has persisted for at least 6 months and documents on at least two occasions and is classified as high or low risk. The high-risk variable is hydronephrosis, hydroureter, chronic kidney disease, recurrent UTI, or urinary incontinence with skin sequalae.

The scientific background for the application of BonT-A in the external urethral sphincter in patients with DESD is based on its known effect of blocking the presynaptic vesicular release of acetylcholine (ACh) at the neuromuscular junction. This leads to temporary reversible chemodenervation of the targeted muscle [6].

BOTOX is the brand name for the formulary that uses onabotulinum-A, serotype A Onabotulinum-A neurotoxin, as a therapeutic agent.

\section{Material and Methods}

A prospective single-armed cohort study was designed. From January 2016 to May 2019, children complaining of LUTS and diagnosed with Detrosor External sphincteric dyssynergia (DESD) on EMG and video-urodynamic, with a $\mathrm{Qmax}<15 \mathrm{ml} / \mathrm{sec}$. Patients with prior urethral or bladder surgery, posterior urethral valve, anorectal congenital anomalies and detrusor-internal sphincter dyssenergia are excluded. Also Non complicated type I excluded from the study. The study was conducted according to Declaration of Helsinki [7] and was approved by our Institute Ethical Committee.

Diagnosis requires pressure flow electromyographic evidence of bladder emptying occurring simultaneously with involuntary striated sphincter contraction in the absence of any element of abdominal straining, either in an attempt to augment bladder contraction or as aresponse to discomfort during urination.

Preoperatively all children were evaluated by clinical history including details of any neurological disease or injury, familial history. Then, details of delivery and perinatal life and the milestones of development were included in the history. The history also included age of bladder and bowl control, voiding pattern, potty training, character of the stream, outflow pattern, urinary leakage and sensation pattern. Periods of dryness and incontinence were recorded accurately.

Physical examination included abdominal, genital, perineal, anal and careful inspection of the child's back. Careful neurological examination was an essential component which included perianal and perineal sensation to pin prick and light touch.
Sacal arc reflexes were examined and eliciting carefully. These included anal sphincter tone, bulbocavernous and cutaneous anal (wink) reflex, suprapubic tap reflex and catheter tug reflex (patients with indwelling catheters). Motor and sensory lower extremities evaluation was taken.

Laboratory studies included urine analysis, urine culture, serum creatinine and/or cystatin C. Imaging included ultrasound, voiding cystourethrography, excretory urography, magnetic resonance imaging and urodynamic studies including pressure flow, electromyography and uroflowmetry. Video-urodynamic was done to confirm the diagnosis and exclude detrusor internal sphincter dyssenergia. Classification of DESD According to Blaivas and coworkers8 have described three main types of DESD. Type 3 not mentioned in last national in the International Continence Society (ICS) report but still valid as subgroup [8] .

Type $1 \mathrm{DSD}$, there is a progressive increase in external urinary sphincter (EUS) contraction activity that peaks at maximal detrusor contraction followed by sudden relaxation of the EUS as the detrusor pressure declines allowing urination. Type 2 occurs with continuous EUS contraction throughout the entire detrusor contraction resulting in urinary obstruction or inability to urinate [9].

In type 3, there is a crescendo-decrescendo pattern of sphincter contraction that results in outlet obstruction throughout the entire detrusor contraction. Non complicated type I excluded from the study.

Ultrasound examination evaluated renal size and structure, cortex thickness, presence and degree of hydronephrosis, ureteral dilation (ureterectasies), bladder volume, bladder wall thickness and postvoiding residual (PVR) urine volume. Nuclear medicine clearance study may be indicated if renal function impairment is suspected.

Capacity $(\mathrm{mL})=(2+$ age [years] $) \times 30$ (Kofffrmula) was calculated before urodynamic study and cystography to avoid complications. Consenting patients received 50UI of BTA (BOTOX, Allergan pharmaceuticals, Clonhaugh coolock, D17 E400, Duplin, Irland) diluted in $4 \mathrm{ml}$ of saline solution $12.5 \mathrm{U} / \mathrm{ml}$ ) injected transurethrally into the external sphincter ( 4 sites, $1 \mathrm{ml} / \mathrm{site}$ ) using a $10 \mathrm{~F}-17 \mathrm{~F}$ rigid cystoscope in general anesthesia according to child age, sex and urethral diameter. A Foley catheter was inserted transurethrally only in patients with postoperative urinary retention. All patients were discharged the next day after voiding without problems. Patients were assessed 
at baseline and at 2, 6 and 12 months postoperatively by means of uroflowmetry with post - void residual urine volume scan (PVR urine), IPSSQoL questionnaire and a self-administered Patient Reported Outcomes (PROs) questionnaire including questions on the Patient Global Impression of Improvement (PGI-I; range 1-7), of Satisfaction (PGI-S; range 0-5) and of Efficacy of the procedure (PGI-E; range 0-5) with higher score indicating better outcome. One month after treatment, all patients underwent video-urodynamic examination with EMG [10]

\section{Results}

Of 28 consecutive patients fulfilling the inclusion criteria, 3 patients were excluded (two with sign of posterior urethral valve at cystoscopy, and one none consenting to the study).

Symptoms were slow stream (22/25), splitting/ spraying (18/25), intermittency (21/25), hesitancy $(22 / 25)$, straining $(15 / 25)$, and terminal dribbling $(9 / 25)$. The primary outcome measure was a reduction of IPSS > from baseline. The secondary outcome measures were maximum urinary flow (Qmax), PVR, IPSS-QoL item score and PROs.

Table (1): Slow stream distribution along treatment course.

\begin{tabular}{lll}
\hline Slow stream $(22 / 25)$ & No. & $\%$ \\
\hline 6 months post intervention & 6 & 27 \\
1 year post intervention & 11 & 50 \\
2 year post intervention & 15 & 68 \\
\hline
\end{tabular}

**Highly significant at $p \leq 0.01$.

Table (2): Splitting/spraying distribution along treatment course.

\begin{tabular}{lll}
\hline Splitting/spraying (18/25) & No. & $\%$ \\
\hline 6 months post intervention & 9 & 50 \\
1 year post intervention & 14 & 77 \\
2 year post intervention & 15 & 83 \\
\hline
\end{tabular}

**Highly significant at $p \leq 0.01$.

Table (3): Intermittency distribution along treatment course.

\begin{tabular}{lll}
\hline Intermittency $(21 / 25)$ & No. & $\%$ \\
\hline 6 months post intervention & 5 & 23 \\
1 year post intervention & 4 & 19 \\
2 year post intervention & 7 & 33 \\
\hline
\end{tabular}

**Highly significant at $p \leq 0.01$.
Table (4): IPSS, Q-Max and Mean PVR (25 patients) along treatment course.

\begin{tabular}{lccc}
\hline & $\begin{array}{c}\text { Mean } \\
\text { IPSS }\end{array}$ & $\begin{array}{c}\text { Mean } \\
\text { Q-Max }\end{array}$ & $\begin{array}{c}\text { Mean } \\
\text { PVR }\end{array}$ \\
\hline Pre-operative & $19.6 \pm 7.6$ & 7.2 & 34.2 \\
6 months post intervention & $12.9 \pm 5.3$ & 11.3 & 16.3 \\
1 year post intervention & $11.5 \pm 6.2$ & 11.5 & 11.6 \\
2 year post intervention & $11.3 \pm 1.2$ & 17.3 & 10.3 \\
\hline
\end{tabular}

Postoperatively post-void residual urine decreased by $30 \%$, detrusor leak point pressure decreased significantly by a mean \pm SD of $66 \pm 18$ vs $37 \pm 4 \mathrm{~cm} \mathrm{H} 2 \mathrm{O}$ and uroflowmetry showed a marked increase in maximum urine flow of $7 \pm 2$ vs $17.3 \pm$ $8 \mathrm{ml}$ per second.

A statistically significant reduction in mean IPSS from 19.6 \pm 7.6 to $12.9 \pm 5.3$ was observed at 6 months follow-up, to11.5 \pm 6.2 at 12 months follow-up and to $11.3 \pm 1.2$ at 24 months $(p=0.145)$. $\mathrm{Q}$ max mean value increased from 7.2 to $11.3 \mathrm{ml} / \mathrm{s}$ at 6 months, rising to $11.5 \mathrm{ml} / \mathrm{s}$ at 12 months and to $12.3 \mathrm{ml} / \mathrm{s}$ at 24 months $(p=0.4101)$. Mean PVR urine decreased from $34.2 \%$ to 16.3 at 6 months, by $11.6 \%$ at 12 months and by $10.3 \%$ at 24 months $(p=0.4201)$.

Table (5): Relation of dyssynergia type and IPSS, Q-Max and Mean PVR (25 patients) 2 years after treatment.

\begin{tabular}{lllcc}
\hline Dyssynergia & No. & $\begin{array}{l}\text { Mean } \\
\text { IPSS }\end{array}$ & $\begin{array}{c}\text { Mean } \\
\text { Q-Max }\end{array}$ & $\begin{array}{c}\text { Mean } \\
\text { PVR urine }\end{array}$ \\
\hline Type 1 & 4 & 12.3 & 11.5 & 11 \\
Type 2 & 18 & 7.9 & 10.1 & 8 \\
Type 3 & 3 & 12.3 & 13.4 & 10.8 \\
All types & 25 & $11.3 \pm 1.2$ & 17.3 & 10.3 \\
\hline
\end{tabular}

A statistically significant reduction in mean IPSS to 12.3 was observed at 2 year post intervention in type I, to 7.9 in type II and to 12.3 in type III. Q max mean value increased to 11.5 in type I, to 10.1 in type II and to 13.4 in type III. Mean PVR decreased to $11 \%$ in type I, to $8 \%$ in type II and to $10.8 \%$ in type III.

No systemic adverse effects occurred and 12 patients $(63 \%)$ reported self-limiting local side effects related to the procedure: $15(60 \%)$ hematuria, $16(64 \%)$ stranguria, $9(36 \%)$ postoperative urinary retention requiring transitory catheterization.

After onabotulinum-A toxin injection all except 1 patient were able to void without catheterization. 
Vesicoureteral reflux was found in 5 male patients at baseline. They underwent follow-up cystourethrogram that showed complete disappearance of the reflux in two of them and improvement degree of reflux in one.

Transurethral injections of Botox showed statistical improvement of patient's sphincter dysfunction.

Three injections at eight month intervals provided long term (nine to 12 months) efficiency.

\section{Discussion}

Without proper treatment, more than $50 \%$ of men with DSD will develop significant complications, such as VUR, upper tract deterioration, urolithiasis, urosepsis, and ureterovesical obstruction. Transurethral injections of Botox showed statistical improvement of patient's sphincter dysfunction [3]. Three injections at eight month intervals provided long term (nine to 12 months) efficiency [11].

Gallien et al., published a trial evaluating the effectiveness and safety of Botox in 86 patients, 58 of whom were women, with detrusor sphincter dyssynergia secondary to multiple sclerosis. 54 Subjects were randomized to intrasphincteric injection of Botox vs placebo. Compared to placebo, Botox significantly increased voiding volume $(p=0.02)$ and reduced pre-micturition $(p=0.02)$ and maximal detrusor pressures $(p=0.02)$ in his study. In our study there was significantly increased voiding volume $(p=0.02)$ and reduced premicturition $(p=0.02)$ and maximal detrusor pressures $(p=0.02)$ in his study [12]

Desrosiers et al., concluded that there are evidence suggesting decreased postvoid residual, maximum urethral closure pressure, and maximum voiding detrusor pressure after treatment with Botox-while still protecting the upper urinary tractindicates that patients with detrusor sphincter dyssynergia may benefit from treatment with botulinum toxin A [13]. Soler et al., published a trial evaluating thePVR urine was significantly reduced following urethral injection of botulinum toxin (from 227 to $98 \mathrm{ml}, p<0.01$ and from 63 to $27 \%$, $p<0.01)$. Their study focused on ninety-nine consecutive adult men with SCI (72 tetraplegic and 27 paraplegic) [14]

Our study revealed decrease of post voiding residual urine from $34.2 \%$ to $10.3 \%$ at 24 months. Kroll concluded that botox injection has shown effectiveness in the treatment of detrusor sphincter dyssynergia when injected into sphincterseither transurethral or trans perineally [15]. Felony and Leslie and concluded that the botulinum toxin injections to the urethral sphincter is reasonable primary treatment strategy when conservative treatments fail [16]

\section{Conclusion:}

Urethral sphincter onabotulinum-A toxin injection could be considered a reliable treatment modality in children with non-neurogenic neurogenic bladder after the failure of conservative therapy. External sphincter injection of BTA could be considered as a minimally invasive treatment option in patients with detrusor-external sphincter dyssenergia if the promising results of the present study will be confirmed in prospective randomized trials.

\section{References}

1- YOSHIMURA N. and de GROAT, W.C.: Neural control of the lower urinary tract. Int. J. Urol., 4: 111-125, 1997.

2- de GROAT W.C., BOOTH A.M. and YOSHIMURA N.: Neurophysiology of micturition and itsmodification in animal models of human disease. In: The Autonomic Nervous System. Nervous Control of the Urogenital System, ed. by C.A. Maggi, Hartwood Academic, London, Vol. 3, pp. 227-289, 1993.

3- RALEVIC V. and BURNSTOCK G.: Receptors for purines and pyrimidines. Pharmacol. Rev., 50: 413-492, 1998.

4- YOSHIMURA N. and CHANCELLOR M.: Physiology and pharmacology of the bladder and urethra. In: Campbell-Walsh Urology. Wein A, Kavoussi, Novick, Partin, Peters (Eds). 10 th Edition, pp 1786-1833, 2012.

5- STOFFEL J.T., PETERSON A.C., SANDHU I.S., SUSKIND A.M., WEI J.T. and LIGHTNER D.J.: AUA White Paper on Nonneurogenic Chronic Urinary Retention: Consensus Definition, Treatment Algorithm, and Outcome End Points. J. Urol., 198 (1): 153-160, 2017.

6- HACKLER R.H.: A 25-year prospective mortality study in the spinal cord injured patient: Comparison with the long-term living paraplegic. J. Urol., 117: 486-8, 1977.

7- World Medical Association. Declaration of Helsinki, 4 th (Somerset West) amendment, 1996.

8- BLAIVAS J.G., SINHA H.P., ZAYED A.A. and LABIB K.B.: Detrusor-external sphincter dyssynergia. J. Urol., 125: $542-4,1981$

9- D'ANCONA C., HAYLEN B., MATTHIAS OELKE M., ABRANCHES-MONTEIRO L., ARNOLD E., GOLDMAN H. and HAMID R., et al.: The International Continence Society (ICS) report on the terminology for adult male lower urinary tract and pelvic floor symptoms and dysfunction. In ICS STANDARDS 2020-2021. Wiley Periodicals LLC, 2020.

10- KOFF S.A.: Estimating bladder capacity in children. Urology, 21 (3): 248, 1983.

11- CHANCELLOR M.B., RIVAS D.A., ABDILL C.K., STAAS Jr. W.E., BENNETT C.J., FINOCCHIARO M.V., RAZI S., BENNETT J.K., GREEN B.G., FOOTE J.E., 
et al.: Management of sphincter dyssynergia using the sphincter stent prosthesis in chronically catheterized SCI men. J. Spinal Cord Med., 18 (2): 88-94, 1995.

12- GALLIEN P., REYMANN J.M., AMARENCO G., NICOLAS B., de SÈZE M. and BELLISSANT E.: Placebo controlled, randomised, double blind study of the effects of botulinum A toxin on detrusor sphincter dyssynergia in multiple sclerosis patients. J. Neurol. Neurosurg Psychiatry, 76 (12): 1670-1676, 2005.

13- LAUREPHILE DESROSIERS L. and KNOEPP L.R.: Botulinum Toxin A: A Review of Potential Uses in treat- ment of Female Urogenital and Pelvic Floor Disorders. Ochsner Journal, 20: 400-409, 2020.

14- SOLER J.M., PREVINAIRE J.G. and HADIJI N.: Predictors of outcome for urethral injection of botulinum toxin to treat detrusor sphincter dyssynergia in men with spinal cord injury. Spinal Cord, 54: 452-456, 2016.

15- KROLL P.: The Current Role of Botox in a Pediatric Neurogenic Bladder Condition. Current Bladder Dysfunction Reports, 14: 115-123, 2019.

16- FELONY M.P. and LESLIE S.W.: Bladder sphincter Dyssynergia. Stat Pearls Publishing, 2021.

\section{حقن عضلة الصمام الخارجى للبول بمادة البوتكس

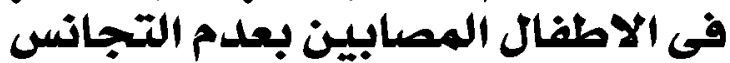

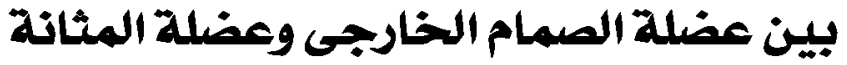

الهدف من البحث: تقييم التَثير الناتج عن حقن الصمام الخارجى اللبول بمادة البوتكس فى الاطفال المصابين بعدم التجانس بين عضلة الصمام الخارجى البول وعضلة المثانة لتقليل مقاومة مجرى البول البعل وتحسين تدفق البول.

المرضى وطرق البحث: تمت الدراسة على مY طفل من عمر ع حتى 10 عام (متوسط V سنوات) المصابون بعدم تجانس بين عضلة المثانة

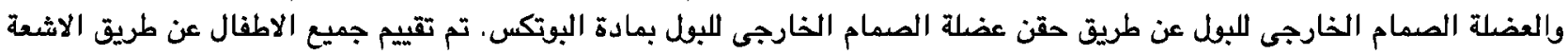

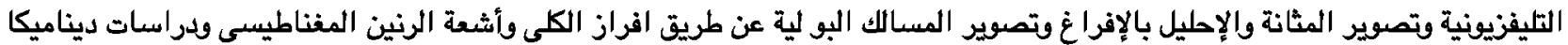

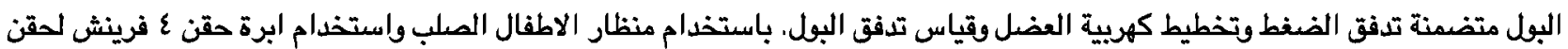

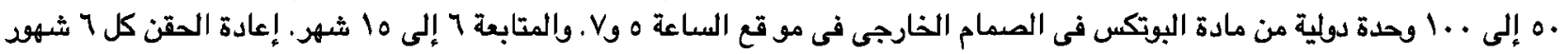

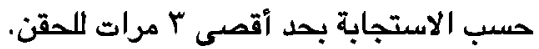

النتائج: مباشراً بعد الحقن تمكن كل الحالات من التبول بدون استخدام القسطرة عدا طفل واحد . لم تحدث أى مضاعفات حادة. كمية البل

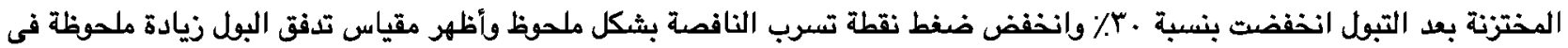

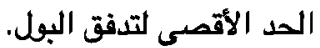

الآستتاج: يمكن اعتبار حقن البوتكس فى الصمام الخلفى فى الاطفال الذين يعانون من المثانة العصبية غير العصبية علاج موثوق بعد الفثل فى محاولات العلاج التحفظى. 